Journal of the Science of

Food and Agriculture

\title{
Management practices and forage quality affecting the contamination of milk with anaerobic spore forming bacteria
}

\begin{tabular}{|r|l|}
\hline Journal: & Journal of the Science of Food and Agriculture \\
\hline Manuscript ID: & JSFA-14-1058.R1 \\
\hline Wiley - Manuscript type: & Research Article \\
\hline Date Submitted by the Author: & n/a \\
\hline Complete List of Authors: & $\begin{array}{l}\text { Zucali, Maddalena; Università di Milano, Dipartimento di Scienze Agrarie e } \\
\text { Ambientali } \\
\text { Bava, Luciana; Università di Milano, Dipartimento di Scienze Agrarie e } \\
\text { Ambientali } \\
\text { Colombini, Stefania; Università di Milano, a Dipartimento di Scienze Agrarie } \\
\text { e Ambientali } \\
\text { Brasca, Milena; Istituto di Scienze delle Produzioni Alimentari, CNR } \\
\text { Decimo, Marilù; Istituto di Scienze delle Produzioni Alimentari, CNR } \\
\text { Morandi, Stefano; Istituto di Scienze delle Produzioni Alimentari, CNR } \\
\text { Tamburini, Alberto; Università di Milano, Dipartimento di Scienze Agrarie e } \\
\text { Ambientali } \\
\text { Crovetto, G. Matteo; Università di Milano, Dipartimento di Scienze Agrarie } \\
\text { e Ambientali }\end{array}$ \\
\hline Key Words: & \begin{tabular}{l} 
silage , Clostridium , milk, management practices, spore \\
\hline
\end{tabular} \\
\hline
\end{tabular}


| Running title: Management practices, forage quality and milk and cheese anaerobic spore contamination

\title{
Management practices and forage quality affecting the contamination of milk and-cheese-with anaerobic spore forming bacteria
}

Maddalena Zucali*, Luciana Bava*, Stefania Colombini*, Milena Brasca $§$, Marilù

Decimo $\S$, Stefano Morandi§, Alberto Tamburini*, G. Matteo Crovetto*

*Università degli Studi di Milano, Dipartimento di Scienze Agrarie e Ambientali, via Celoria 2, 20133

Milano, Italy

$\S$ Istituto di Scienze delle Produzioni Alimentari, CNR, via Celoria 2, 20133, Milano, Italy

Corresponding author: Stefania Colombini stefania.colombini@unimi.it

\begin{abstract}
BACKGROUND Anaerobic spore forming bacteria (ASFB) in milk derive from the farm environment and the use of silages and management practices are the main responsible of milk ASFB contamination.

The aim was to evaluate the relationships between feeding, milking routine and cows hygiene and milk and Grana Padano cheese (produced with and without lysozyme) ASFB contamination.

RESULTS The study involved 23 dairy farms. ASFB in corn silage were on average $2.34 \pm 0.87 \log _{10} \mathrm{MPN} \mathrm{g}{ }^{-1}$. For grass, Italian ryegrass and alfalfa, ASFB $\left(\log _{10} \mathrm{MPN} \mathrm{g} \mathrm{g}^{-1}\right)$ were numerically higher for silages (3.22) than hays (2.85). The use of corn silages of high quality (high lactic and acetic acids concentrations) decreased the milk ASFB contamination, whilst the use of herbage silages did not affect it. The presence $(>40 \%)$ of cows with dirty udders increased the ASFB contamination of milk, while forestripping had a positive effect $(-9 \%$ ASFB).

Ripened Grana Padano had ASFB count below the analytical limit; Cl. tyrobutyricum DNA was found only in wheels produced without lysozyme which also showed late blowing.
\end{abstract}


CONCLUSION The factors increasing milk spore contamination were corn silage quality, cow udder hygiene and inadequate milking routine. Late blowing was present only in cheeses without lysozyme.

Keyword: silage, Clostridium, milk, management practices, spore

\section{INTRODUCTION}

It is generally known that the gas-producing anaerobic spore forming bacteria (ASFB) are the main responsible of the defect called late blowing in hard cheeses. Late blowing can lead to off-flavors and excessive gas formation in cheese, due to bacteria ability to convert lactic acid into butyric acid, hydrogen, and carbon dioxide at relatively low $\mathrm{pH}$. Moreover, spores of anaerobic bacteria survive milk pasteurization and pass unaffected into cheese. Among ASFB, Clostridium tyrobutyricum is particularly associated with late blowing during the ripening process of hard-cooked-cheeses ${ }^{1}$ but also other Clostridium species were found responsible for the problem, e.g. Clostridium sporogenes, Clostridium beijerinckii and Clostridium butyricum. ${ }^{2,3}$

The late blowing is a relevant defect of Grana Padano PDO cheese production: $15 \%-35 \%$ of total production showed this problem ${ }^{4}$ and to inhibit late blowing of cheese the addition of lysozyme to the vat milk (20-30 ppm) is allowed in Grana Padano production. ${ }^{5}$ The threshold value of spore concentration in milk causing late blowing is between 600 and 1000 most probable number (MPN) L ${ }^{-1} 6$ but some authors ${ }^{4}$ reported the problem also with a value lower than $100 \mathrm{MPN} \mathrm{L}^{-1}$. The average concentration of spore in milk produced in Lombardy (North Italy) was $220 \mathrm{MPN} \mathrm{L}^{-1}$ in $2013 .^{6}$

Spores of butyric acid bacteria in milk derive from the farm environment and the most important source of contamination is the use of silages in the ration ${ }^{7}$; hence, it is 
important to determine the spore content of the forages fed to cows but information about concentrations of butyric acid bacterial spores in farm-scale silages is still rather scarce. $^{8}$ It is well known that high concentrations of ASFB are associated with anaerobic instability of silage: the creation and maintenance of anaerobic conditions in ensiled forages are important to prevent the growth of aerobic microorganisms but, in practice, exposure of silage to air is unavoidable. The growth of clostridia takes place during the acidification phase at the beginning of silage process ${ }^{9}$ and continues during the storage period when small amounts of air can penetrate into the silage, for instance, because silage covers (usually plastic sheets) are not completely airtight. ${ }^{7}$ When silage is exposed to air, oxygen penetrates deeply into it, and aciduric aerobic organisms (e.g., yeast) consume oxygen and the substances that inhibit the clostridia growth, i.e., organic acids produced by bacteria anaerobic fermentation. The consumption of both acids and oxygen leads to the development of micro-niches with less inhibitory activity, which might allow the growth of clostridia. ${ }^{10}$ In the Po valley corn silage, the main forage used in the total mixed ration (TMR) of dairy cow, has high quality for ensiling because of its relatively high DM content, low buffering capacity, and adequate levels of fermentable sugars. ${ }^{11}$ Corn silage cores usually contain less than $3 \log _{10} \mathrm{MPN} \mathrm{g}^{-1}$ of butyric acid bacteria spores ${ }^{9,12}$ but as demonstrated by Vissers et al. ${ }^{1}$ spore concentration is significantly higher in corn silage surface layer than in the core. The same authors concluded that on Dutch farms, corn silage was a more important source of ASFB contamination in milk than grass silage.

Although a simulated model proposed by Vissers et $a l^{7}$ demonstrated that silage contamination is the main source of spore milk content, other identified sources are soil, feces and bedding materials. Spores survive the passage through the digestive tract of the cows and are excreted with the feces. A direct relation between spore content in feces and in milk was obtained by Nadeau et al..$^{13}$ The same authors also associated the 


\section{MATERIALS AND METHODS}

\section{Farm characteristics}

A total of 23 farms were chosen from 400 farms belonging to the same milk cooperative in Lombardy, in the North of Italy and their total production was destined to produce Grana Padano PDO cheese. The choice of the 23 farms was based on the following criteria: location in the flatland; lactating cows housing in cubicles; herringbone milking parlour; herds with >50 milking cows; feeding systems based on TMR with or without herbage silages.

Each farm was visited once during the summer 2012 and a questionnaire was filled out to collect information on milking parlour, milking routine, TMR composition, crop characteristics. Information about milk yield and quality of each farm was provided by the milk cooperative. Bulk milk was refrigerated at $11^{\circ} \mathrm{C}$ after the two daily milkings, following the indication of Grana Padano PDO production rules.

\section{Sampling and analyses}


During each visit, the forages (hays and silages) used in the lactating cow TMR and the TMR were sampled. Samples were dried in a forced air oven $\left(55^{\circ} \mathrm{C}\right.$ for $\left.48 \mathrm{~h}\right)$ and ground to pass through a $1 \mathrm{~mm}$ sieve using a Wiley mill (Pulverisette 19, Fritsch, IdarOberstein, Germany) prior to chemical analyses. Forages and TMR were analyzed for Dry Matter (DM), ash, Crude Protein (CP) and ether extract with the methods of $\mathrm{AOAC}^{16}$ and starch with the method $\mathrm{AOAC}^{17}$; NDF was analyzed with the method of Mertens $^{18}, \mathrm{ADF}$ and ADL with the method of Van Soest et al. ${ }^{19}$ Extracts from fresh samples of silages were prepared and $\mathrm{pH}$ was measured. Silage samples were also analyzed for lactic acid and volatile fatty $\operatorname{acids}^{20}$ and ammonium-N by direct distillation and titration using a Kjeltec 2300 analyzer (Foss Analytical A/S, Hillerød, Denmark).

Samples were analyzed in situ for rumen NDF digestibility at $48 \mathrm{~h}$ (NDFD) according to Spanghero et al. ${ }^{21}$. Energy value of forages was calculated by $\mathrm{NRC}^{22}$ equations.

Bulk milk was sampled from the tank at the end of the evening milking the day of the visit, the samples were transported to the laboratory under refrigeration $\left(4^{\circ} \mathrm{C}\right)$ no later than $12 \mathrm{~h}$ from collection, and immediately subjected to chemical and microbiological analysis.

For microbiological analysis forage samples were chopped for $1 \mathrm{~min}$ in a sterile homogenizer, then $(10 \mathrm{~g})$ suspended in a $1: 10$ peptone salt solution (PPS; $1 \mathrm{~g}$ of bacteriological peptone and $9 \mathrm{~g}$ of sodium chloride per liter), and homogenized twice for 2 min at maximum speed using a Stomacher (BagMixer 400, Interscience). The raw milk samples were analysed directly.

Gas-forming anaerobic spores and propionibacteria were determined in forage samples. Anaerobic spore content was obtained throughout the MPN. MPN enumeration was performed with three 10 -fold dilutions with three tubes at each dilution. The culture medium used for MPN was prepared with reconstituted skimmed milk $(10 \% \mathrm{wt} / \mathrm{v})$ supplemented with a solution of yeast extract (1.0\%), sodium lactate $(3.36 \%)$, sodium 
acetate $(1.0 \%)$, cysteine $(0.2 \%)$ with vaseline/paraffin $(1: 1, \mathrm{wt} / \mathrm{wt})$ seals. The heat treatment applied to the inoculated milk medium was $80^{\circ} \mathrm{C}$ for $10 \mathrm{~min}$. The incubation period was 7 days at $37^{\circ} \mathrm{C}$. In order to detect the presence of Clostridium species $(\mathrm{Cl}$. tyrobutyricum, $\mathrm{Cl}$. butyricum, $\mathrm{Cl}$. beijerinckii; $\mathrm{Cl}$. sporogenes,) positive tubes were analyzed by multiplex PCR according to Cremonesi et al. ${ }^{23} \mathrm{P} 2$ agar containing peptone $5 \mathrm{~g}$; beef extract, $3 \mathrm{~g}$; yeast extract, $5 \mathrm{~g}$; sodium lactate, $1 \mathrm{~g}$; agar $15 \mathrm{~g}$ per litre ${ }^{24}$ was used for anaerobic enumeration of propionibacteria at $30^{\circ} \mathrm{C}$ for 7 days. For incubation in anaerobic conditions, jars with anaerocult A (Merk KGaA, Darmstadt, Germany) were used.

Milk bulk samples were analyzed for fat, protein, lactose, urea using a Fourier transform infrared analyser (Milkoscan FT6000; Foss Analytical A/S). Somatic cell counts were determined by Fossomatic SC.

Milk bulk samples were also examined for standard plate count (SPC) and coliform count (CC) using Petrifilm (3M Canada, London, Ontario, Canada) and plates were incubated respectively at $30^{\circ} \mathrm{C}$ for 72 and $24 \mathrm{~h}$. Lactic acid bacteria (LAB) were determined on de Man Rogosa and Sharpe (MRS) agar (Biolife, Milan, Italy); the plates were incubated anaerobically at $30^{\circ} \mathrm{C}$ for $72 \mathrm{~h}$. Propionibacteria and anaerobic spore content were determined as previously described.

\section{Cow cleanliness}

Hygiene scores of dairy cows were assessed through direct observation in the milking parlour at each farm visit according to Schreiner and Ruegg ${ }^{25}$ : udder, flanks and legs of each milked cow (4216 cows) were scored in the same way based on a 4-point scale system, where score 1 indicates very clean skin while score 4 indicates skin completely covered with dirt. Later on the percentage of animals with score 3 and 4 for udder, flanks and legs was calculated for each farm. 


\section{Cheese production}

The farms were divided into two groups (HIGH and LOW) on the basis of the spore forming count in milk and the threshold value used to divide the bulk milk was $2.5 \log _{10}$ MPN L ${ }^{-1}$. The milk of the two groups was separately collected and within each group it was used for two different Grana Padano cheese production with and without the addition of lysozyme.

Grana Padano cheese was made with milk partially skimmed by natural creaming process. The milk was transferred to copper bell-shaped vats containing $1000 \mathrm{~L}$ and a natural whey culture was added as a starter. Milk was then heated to $32{ }^{\circ} \mathrm{C}$, calf rennet was added. The resulting curd was broken up into small granules to the size of grains of rise after $10 \mathrm{~min}$ from the rennet addition; it was then cooked by increasing the temperature to $54-55{ }^{\circ} \mathrm{C}$ in about $10 \mathrm{~min}$ and constantly stirred. The broken curd was then left to rest maintaining the temperature at $53{ }^{\circ} \mathrm{C}$ for $60 \mathrm{~min}$. The cheese mass was then cut in two wheels and transferred into traditional moulds for 2 days, salted in brine for 22 days and ripened at $15-22{ }^{\circ} \mathrm{C}$.

Sixteen cheese wheels were obtained: 8 with milk of HIGH group (4 with lysozyme and 4 without addition) and 8 with milk of LOW group (4 with lysozyme and 4 without addition). The presence of Clostridium species and anaerobic spore content in cheese samples were determined as previously described. X-Ray analysis was performed for cheese wheels produced with and without the addition of lysozyme from HIGH and LOW milk group. X-ray analysis, commonly used in dairy plants to detect defects due to bacterial fermentation in Grana Padano cheese, was performed at 7 months of ripening following the indications of the Quality control handbook of the cheese plant.

\section{Statistical analysis}

Bacterial counts were expressed as base 10 logarithm, for statistical analysis. 
Relationships among farm dimension, use of forestripping procedure, use of predipping procedure, cow udder hygiene, microbiological quality of raw milk (standard plate count, lactic acid bacteria, anaerobic spores, propionibacteria and coliform counts), anaerobic spores in corn silage and in TMR, silage propionic acid, silage acetic acid, silage lactic acid were evaluated through a multiple correspondence analysis (Proc CORRESP; $\mathrm{SAS}^{26}$,) to find a two dimensional graphical representation of the rows and columns of a contingency table.

Difference in chemical composition and nutritive value between silage (with the exclusion of corn silage) and hay samples and among forage species were tested by Proc $\mathrm{GLM}^{26}$ as follows:

$\mathrm{Yijk}=\mu+\mathrm{Ci}+\mathrm{Fj}+\mathrm{Ci} * \mathrm{Fj}+$ eijk

Where:

Yijk = dependent variables;

$\mu=$ general mean;

$\mathrm{Ci}=$ conservation effect $(\mathrm{i}=1-2$; silage vs hay);

$\mathrm{Fj}=$ forage species effect $(\mathrm{J}=1-3$; alfalfa, grass and Italian ryegrass $)$;

eijk= residual error.

The characteristics of the farms based on LOW or HIGH milk spore forming count were identified by Proc $\mathrm{GLM}^{26}$ with the following model:

$\mathrm{Yijkl}=\mu+\mathrm{Gi}+\mathrm{Dj}+\mathrm{Sk}+\mathrm{eijkl}$

Where:

Yijkl = dependent variables;

$\mu=$ general mean;

$\mathrm{G}_{\mathrm{i}}=$ spore count in bulk milk effect $\left(\mathrm{i}=1-2 ;<2.5 \log _{10} \mathrm{MPN} \mathrm{L}^{-1}\right.$ or $\left.\geq 2.5 \log _{10} \mathrm{MPN} \mathrm{L}^{-1}\right)$;

$D_{J}=$ farm dimension in term of dairy cows number $(j=1-2 ;<100$ or $\geq 100)$; 
$\mathrm{S}_{\mathrm{k}}=$ corn silage, $\%$ on total DM $(\mathrm{k}=1-2 ;<37 \%$ or $\geq 37 \%)$;

eijkl $=$ residual error

Data are reported as Least Square Means

\section{RESULTS AND DISCUSSION}

Chemical composition, nutritive value and anaerobic spore forming count of forages

The average forage content in the lactating cow TMR was $560 \pm 49 \mathrm{~g} \mathrm{~kg}^{-1} \mathrm{DM}$. The amount of forage in TMR was adequate and there was a low variability among farms for this parameter $(\mathrm{CV}=8.8 \%)$. Forage quality is a key factor to maintain high quality milk production. ${ }^{2,3,8}$ However, increasing forage proportion, especially silages, could be related to a higher risk of milk spore contamination. ${ }^{1,27}$ In the present study, corn silage was included in the TMR of all farms (on average $363 \mathrm{~g} \mathrm{~kg}^{-1} \mathrm{DM}$ ) whilst other silages (grass, Italian ryegrass or alfalfa) were used in half of the farms surveyed (48\%). Particularly, grass and Italian ryegrass silages were used in $30 \%$ of farms and alfalfa silage was used in $26 \%$ of farms. The amount of silages, other than corn silage, was on average $105 \pm 57 \mathrm{~g} \mathrm{~kg}^{-1} \mathrm{DM}$ with a wide range of variation $\left(42-262 \mathrm{~g} \mathrm{~kg}^{-1}\right)$.

Average chemical composition, nutritive value and NDFD of corn silages were: ash 50.3, CP 77.9, EE 32.8, NDF 454, ADF 294, ADL 45.9, starch 298 and NFC $385 \mathrm{~g} \mathrm{~kg}^{-1}$ $\mathrm{DM}, \mathrm{NE}_{1} 6.54 \mathrm{MJ} \mathrm{kg}^{-1} \mathrm{DM}$ (expressed at 3X level of maintenance) and NDFD $498 \mathrm{~g} \mathrm{~kg}^{-}$ ${ }^{1}$ NDF. The DM content was on average $351 \mathrm{~g} \mathrm{~kg}^{-1}$. Average ASFB $\left(\log _{10} \mathrm{MPN}_{-}-\mathrm{g}^{-1}\right)$ was $2.34 \pm 0.87$ with a great variability among samples $(\mathrm{CV}=38 \%)$. The average ASFB was slightly lower than the value (2.75) reported by Borreani and Tabacco ${ }^{28}$ for corn silages sampled in the peripheral areas of the silos in commercial Italian farms and equal to the value (2.34) reported by Colombari et al. ${ }^{9}$. As demonstrated by Danner et $a l .{ }^{29}$ under constant conditions, the aerobic stability of silages is determined by the 
concentration of acetic acid; in the present study the acetic acid content in corn silage was $19.9 \pm 8.60 \mathrm{~g} \mathrm{~kg}^{-1} \mathrm{DM}$ with a wide variability $(\mathrm{CV}=43.1 \%)$ and this could have affected the aerobic stability of silages and consequently the spore content. Average corn silage $\mathrm{pH}$ was $3.96 \pm 0.18$ and the lactic acid content was $48.2 \pm 13.6 \mathrm{~g} \mathrm{~kg}^{-1} \mathrm{DM}$ whilst no significant levels of butyric acid were detected.

Chemical composition, NDFD and nutritive value of grass, Italian ryegrass, alfalfa hays and silages are reported in table 1 . Silages had higher ash and CP contents $\left(\mathrm{g} \mathrm{kg}^{-1} \mathrm{DM}\right)$ than hays (ash: 71.3 vs $112, \mathrm{P}<0.001$ and $\mathrm{CP}: 101$ vs $129, \mathrm{P}=0.05$, for hay and silage respectively) whilst hays had higher NDF content (557 vs $496 \mathrm{~g} \mathrm{~kg}^{-1} \mathrm{DM}, \mathrm{P}=0.007$, respectively for hays and silages). Silages were also characterized by higher NDFD values than hays (394 vs $476 \mathrm{~g} \mathrm{~kg}^{-1} \mathrm{DM}, \mathrm{P}=0.002$ for hay and silage, respectively). These differences result in a higher organic matter digestibility (OMd) and net energy for lactation $\left(\mathrm{NE}_{1}\right)$ for silages than hays $\left(\mathrm{OMd}=702\right.$ vs $642 \mathrm{~g} \mathrm{~kg}^{-1} \mathrm{DM}, \mathrm{P}=0.01$, for silage and hay, respectively; $\mathrm{NE}_{\mathrm{l}}=4.86$ vs $4.26 \mathrm{MJ} \mathrm{kg}^{-1} \mathrm{DM}, \mathrm{P}=0.02$; for silage and hay, respectively). Overall, the mean values were low showing a poor quality of the forages used in the TMR.

As previously reported, silages were ensiled as wrapped bale silages and the forage was not chopped; wrapping silage offers many advantages compared to hay making: large quantities of forage can be conserved in a short time, forage conservation is less weather-dependent, and silage can be easily mechanized. On the other hand, the disadvantages include an increased risk of moldy and mycotoxin production, an increased risk of listeriosis, clostridial spoilage, and the loss of nutrients due to difficulties in achieving the basic conditions required for stability during the storage of silage. ${ }^{30}$ Furthermore, it has to be underlined that usually baled silages underwent a more restricted fermentation than chopped silages ensiled in bunker silos and that less anaerobic conditions are usually obtained with baled silages than chopped silages. In the 
present study, ASFB tended to be higher for silages (alfalfa, Italian ryegrass and grass) than hays (3.22 vs $2.85 \log _{10} \mathrm{MPN} \mathrm{g}^{-1}$ for silage and hay samples, respectively, $\mathrm{P}=0.09$ ) but differences were not detected among forages. Grass species silages however had a higher ASFB spore content than corn silage (3.22 vs $2.75 \log _{10} \mathrm{MPN} \mathrm{g}{ }^{-1}$ respectively). Concerning alfalfa silage, the average ASFB (3.00 $\left.\log _{10} \mathrm{MPN} \mathrm{g}^{-1}\right)$ was higher than the value (2.11) reported by Colombari et al. ${ }^{9}$ for a sample with a similar DM. On average, alfalfa silages had a very high $\mathrm{pH}$ value (6.03) and a low lactic acid concentration $(9.8 \mathrm{~g}$ $\left.\mathrm{kg}^{-1} \mathrm{DM}\right)$. Similarly, contents of ASFB in silages were not in the range of those reported for grass chopped herbages and for well-conserved haylage.,31,32 Furthermore, differently from what reported by Julien et al. ${ }^{2}$ clostridia were detected in hay samples. Information about concentrations of butyric acid bacteria spores in farm-scale silages is rather scarce. Studies in France conducted in the 1970s showed that about $20 \%$ of grass silages contained more than $10^{5}$ butyric acid bacteria spores, indicating a poor quality of forages $^{8}$ and in agreement with the results of the present study.

Overall, average ASFB content for TMR was $4.75 \pm 0.73 \log _{10} \mathrm{MPN} \mathrm{g}^{-1}$ and higher than the values estimated from the ASFB spore content of the forages.

\section{Effect of silage quality and management practices on anaerobic spore} contamination of milk

The ASFB content in bulk tank milk of farms that used other ensiled forages in the diet, in addition to corn silage $\left(2.73 \log _{10} \mathrm{MPN} \mathrm{L}^{-1}\right)$, did not differ much from the content of farms that used only corn silage $\left(2.78 \log _{10} \mathrm{MPN} \mathrm{L}^{-1}\right)$ (Table 2). This result was probably due to the small quantity of other silages used in the diet $\left(105 \mathrm{~g} \mathrm{~kg}^{-1} \mathrm{DM}\right.$ on average); the results of the present experiment are consistent with a study of Vissers et $a l .{ }^{1}$ which demonstrated that on Dutch farms, corn silage was a more important source of ASFB contamination in milk than grass silage. 
Table 2 shows farm distribution and ASFB values in bulk tank milk considering corn silages quality. Farms that used high quality corn silage (lactic acid $>50 \mathrm{~g} \mathrm{~kg}^{-1} \mathrm{DM}$, acetic acid $>20 \mathrm{~g} \mathrm{~kg}^{-1} \mathrm{DM}$, propionic acid $<1.5 \mathrm{~g} \mathrm{~kg}^{-1} \mathrm{DM}$ ) had a lower spore count in bulk tank milk than the others farms. The concentration of propionic acid in the corn silage seems to influence more the bacterial contamination of milk: farms with low propionic acid content in the corn silage had 13.8\% less ASFB in milk than the other farms. All corn silage $\mathrm{pH}$ values were below the threshold of 4.2 , which can indicate fermentative problems of the silage. High silage $\mathrm{pH}$ could be due to: high dry matter at ensiling $(>50 \% \mathrm{DM})$, cold weather during harvest, slow or poor packing, silage with excess ammonia or urea, clostridial contamination, spoiled or moldy silages, silages containing manure. ${ }^{33}$

Farms characterized by lower ASFB content in corn silage and TMR produced milk with lower level of anaerobic spores than the other farms (table 2). A linear regression analysis indicated that there was a positive relationship between milk ASFB $\left(\log _{10}\right.$ MPN $\left.\mathrm{L}^{-1}\right)$ and corn silage ASFB $\left(\log _{10}\right.$ MPN g $\left.g^{-1}\right)$ content $(y=0.294 *$ ASFB corn silage + $\left.2.075 ; r^{2}=0.217\right)$. It is well known that high concentrations of anaerobic spores are associated with anaerobic instability of silage during the primary fermentation phase. ${ }^{8}$ However, as recently demonstrated by Vissers et al. ${ }^{1}$ milk spore contamination is mainly related to aerobic instability rather than to anaerobic instability problems; therefore, also corn silage, being subjected to aerobic deterioration, has an important effect on milk spore contamination. Management practices, in particular during milking, can influence the quality of bulk tank milk as found by Rasmussen et al. ${ }^{14}$. In the present study (table 3 ) farms that paid more attention to milking routine (use of gloves, forestripping, predipping) achieved the best results in terms of a lower ASFB milk contamination. In particular, farms that carried out forestripping had $-9 \%$ of ASFB in milk. Furthermore, farms that used the 
complete milking routine operations (use of gloves, dry udder clean, forestripping, predipping, postdipping), achieved the lowest ASFB milk contamination. These results are consistent with those of Zucali et al..$^{34}$ who found that the dairy farms which used an accurate milking routine produced milk with the best microbiological quality in terms of standard plate count, propionibacteria and coliform count.

Cow hygiene, in particular of the udder, influenced milk ASFB content as found by some authors. ${ }^{7,13}$ The presence of more than $40 \%$ of animals with dirty udders in farms increased the average ASFB contamination of milk by $15 \%$.

Table 4 shows the frequency of different Clostridium species in the forages and in the TMR collected in -the study. The frequency of $C$. tyrobutyricum was the highest, in particular in corn silage (66.7\%), grass hay $(77.8 \%)$ and TMR samples $(82.6 \%)$. C. beijerinckii was the second species for presence in feeds, particularly in TMR samples (47.5\%). The almost constant detection of C. tyrobutyricum in the sampled forages arises some concern because, as demonstrated by Klijn et al. ${ }^{35}$, late blowing in Gouda cheese was exclusively associated with the growth of $C$. tyrobutyricum and not with the presence of C. beijerinckii or C. sporogenes. In five samples were ASFB were present, none of the tested clostridia was detected. The presence of other Clostridia can be hypothesized; for example Rossi and Dellaglio ${ }^{36}$ detected C. saccharolyticum and $C$. baratii in silages whilst Julien et al. ${ }^{2}$ identified $C$. disporicum as another predominant member of clostridial population in silage. Clostridial species present in forages were consistent with milk spore contamination.eonfirming the strict relationship.

All the tested species were detected in milk samples.

Figure 1 shows the results of multiple correlations between variables. The correspondence analysis divided the variables in four groups. The groups identified different farm situations based on management practices and milk and feeds quality, defined as follows: 1) good management (upper left); 2) low quality of feeds and milk 


\section{Milk and cheese quality}

The ASFB content in milk was 3.14 and $2.33 \log _{10} \mathrm{MPN} \mathrm{L}^{-1}$ respectively for the HIGH and the LOW groups. The characteristics of the farms belonging to the two groups are showed in table 5. The average milk yield of the cows of farms of the HIGH group was lower than that of the LOW group $(\mathrm{P}<0.01)$. No differences between the two groups were observed in the composition and quality of the TMR and in the quality of corn silage. Despite this, the average spore content of corn silage differed between HIGH and LOW groups $\left(2.47\right.$ vs $\left.1.90 \log _{10} \mathrm{MPN} \mathrm{g}^{-1}, \mathrm{P}<0.07\right)$; this could explain the different level of milk contamination. This finding is again consistent with the results of Visser et $a l .{ }^{1}$ who showed a close linkage between corn silage and milk contamination. Milking cows were dirtier in HIGH group than in LOW group; in particular legs and flanks showed the worst results. with a significant difference between groups. SPC and lactic 
acid bacteria $\underline{L A B}$ counts did not differ significantly between the groups, while propionibacteria and $\mathrm{CC}$ were significantly higher in LOW group but not significantly. The milk of LOW and HIGH farm groups was separately collected and cheesemaking trials were carried out in a cheese factory that usually produces Grana Padano cheese. The milk of each group was further divided into two halfs: in one half lysozyme was added into the vat $\left(25 \mathrm{mg}_{-} \mathrm{L}^{-1}\right)$ while no addition was done in the other one. After 7 months of ripening, even if spore count was below the analytical limit $\left(<30 \mathrm{MPN} \mathrm{g}{ }^{-1}\right)$, in all the experimental cheeses both in HIGH and LOW group, the prevalence of $\mathrm{Cl}$. tyrobutyricum was highlighted, by DNA assay, only in cheeses produced without lysozyme, both in LOW and HIGH groups. $\mathrm{Cl}$. tyrobutyricum outgrowth and butyric acid fermentation were confirmed by X-Ray analysis evidencing late blowing defects. It is worthwhile noting that widespread blowing was significantly-lower in cheeses produced with the LOW group milk (Figure 2).

\section{CONCLUSIONS}

The study underlines the relation among forage quality, dairy farm management practices and milk and cheese ASFB contamination. The main risk factors which increase milk spore contamination were spore content of corn silage, scarce cow udder hygiene and inadequate milking routine (lack of forestripping and predipping procedures). The presence in the TMR of herbage silages (107 $\mathrm{g} \mathrm{kg}^{-1} \mathrm{DM}$ on average), did not affect significantly milk spore contamination. In Grana Padano cheese $\mathrm{Cl}$. tyrobutyricum was highlighted after 7 months of ripening only in the wheels produced without addition of lysozymebut the spore caused late blowing only in the wheels produced without addition of lysozyme, confirming the effectiveness of this additive in preventing spore outgrowth by clostridia. 


\section{REFERENCES}

1. Vissers MMM, Driehuis F, Te Giffel MC, De Jong P and Lankveld JMG, Concentrations of butyric acid bacteria spores in silage and relationships with aerobic deterioration. J Dairy Sci 90:928-936 (2007).

2. Julien MC, Dion P, Lafreniere C, Antoun H and Drouin P, Sources of Clestridia clostridia in raw milk on farms. Appl Environ Microbiol 74:20 6348-6357 (2008).

3. Garde S, Arias R, Gaya P and Nuñez M, Occurrence of Clostridium spp. in ovine milk and Manchego cheese with late blowing defect: identification and characterization of isolates. Int Dairy J 21:272-278 (2011).

4. Borreani $G$ and Tabacco E, Low permeability to oxygen of a new barrier film prevents butyric acid bacteria spore formation in farm corn silage. J Dairy Sci 91:4272-4281 (2008).

5. Neviani E, Bottari B, Lazzi C and Gatti M, New developments in the study of the microbiota of raw-milk, long-ripened cheeses by molecular methods: the case of Grana Padano and Parmigiano Reggiano. Front Microbiol 4:1-14 (2013).

6. IZSLER, Istituto Zooprofilattico Sperimentale della Lombardia e dell'Emilia Romagna "Bruno Ubertini”" http://www.izsler.it/ (January 2014).

Field Code Changed

7. Vissers MMM, Driehuis F, te Giffel MC, De Jong $\mathrm{P}$ and Lankveld JMG, Minimizing the level of butyric acid bacteria spores in farm tank milk. $J$ Dairy Sci 90:3278-3285 (2006).

8. Driehuis F, Silage and the safety and quality of dairy foods: a review. Agric Food Sci 22:16-34 (2013). 
9. Colombari G, Borreani G and Crovetto GM, Effect of ensiling alfalfa at low and high dry matter on production of milk used to make Grana cheese. J Dairy Sci 84:2494-2502 (2001).

10. Jonsson A, The role of yeasts and clostridia in silage deterioration. Ph.D. Diss. Swedish University of Agricultural Sciences, Uppsala, Sweden (1989).

11. McDonald P, Henderson AR and Heron SJE, The biochemistry of silage. 2nd edition. Chalcombe Publications, Marlow, Bucks, UK (1991).

| 12. Colombari G, Borreani G and Crovetto GM, Comparison of Lucerne-lucerne silage and ventilated hay in maize silage-based rations for dairy cows for the production of milk destined for Grana cheese. Grass Forage Sci 54:184-194 (1999).

| 13. Nadeau E, Arnesson A and Bengtsson A, Investigation of Elestridial-clostridial spores in Swedish dairy herds. 14th International Symposium Forage Conservation Brno, Czech Republic, pp 80-82 (2010).

14. Rasmussen MD, Galton DM and Petersson LG, Effects of premilking teat preparation on spores of anaerobes bacteria, and iodine residues in milk. $J$ Dairy $S c i$ 74:2472-2478 (1991).

15. Arias C, Oliete B, Seseña S, Jimenez L, Pérez-Guzmán MD and Arias R, Importance of on-farm management practices on lactate-fermenting Clostridium spp. spore contamination of Manchega ewe milk: determination of risk factors and characterization of Clostridium population. Small Rum Res, 111:120-128 (2013).

16. AOAC, Official Methods of Analysis, 16th edn. Association of Official Analytical Chemists, Washington, DC, USA (1995).

17. AOAC, Official Methods of Analysis, 17th edn. Association of Official Analytical Chemists, Washington, DC, USA (2000).

18. Mertens DR, Gravimetric determination of amylase-treated neutral detergent fiber in feeds with refluxing in beakers or crucibles: collaborative study. $J$ AOAC Int 85:1217-1240 (2002).

19. Van Soest PJ, Robertson JB and Lewis BA, Methods of dietary fiber, neutral detergent fiber and non-polysaccharides in relation to animal nutrition. J Dairy Sci 74:3583-3597 (1991).

20. Canale A, Valente ME and Ciotti A, Determination of volatile carboxylic acids (C1-C5i) and lactic acid in aqueous acid extracts of silage by high performance liquid chromatography. J Sci Food Agr 35:1178-1182 (1984). 
21. Spanghero M, Berzaghi P, Fortina R, Masoero F, Rapetti L, Zanfi C, et al, Precision and accuracy of in vitro digestion of neutral detergent fiber and predicted net energy of lactation content of fibrous feeds. J Dairy Sci 93:4855-4859 (2010).

22. NRC, Nutrient Requirement of Dairy Cattle, 7th edn. National Research Council, National Academy of Science, Washington, DC, USA (2001).

23. Cremonesi P, Vanoni L, Silvetti T, Morandi S and Brasca M, Identification of Clostridium beijerinkii, Cl. butyricum, $\mathrm{Cl}$. sporogens, $\mathrm{Cl}$. tyrobutyricum isolated from silage, raw milk and hard cheese by a multiplex PCR assay. $J$ Dairy Res 79:318-323 (2012).

24. Carini S and Casadei S, Contributo alla conoscenza della respirazione e dei metabolismi ossidativi nei propionici, Sci Tec Latt Cas 21:365-378 (1970).

25. Schreiner DA and Ruegg PL, Relationship between udder and leg hygiene scores and subclinical mastitis. J Dairy Sci 86:3460-3465 (2003).

26. SAS 9.2. SAS Inst. Inc., Cary, NC (2009).

27. te Giffel MC, Wagendorp A, Herrewegh A and Driehuis F, Bacterial spores in silage and raw milk. A Van Leeuw J Microbiol 81:625-630 (2002).

28. Borreani $G$ and Tabacco E, The relationship of silage temperature with the microbiological status of the face of corn silage bunkers. J Dairy Sci 93:2620-2629 (2010).

29. Danner H, Holzer M, Mayrhuber E and Braun R, Acetic acid increases stability of silage under aerobic conditions. Appl Environ Microbiol 69:562-567 (2003).

30. Muck RE, Moser LE and Pitt RE, Postharvest factors affecting ensiling, pp 251-304. In Silage Science and Technology. Buxton DR, Muck RE and. Harrison JH ed. Am. Soc. Agron., Crop Sci. Soc. Am., Soil Sci. Soc. Am., Madison, WI (2003).

31. Rammer C, Quality of grass silage infected with spores of Clostridium tyrobutyricum. Grass Forage Sci 51:88-95 (1996).

32. Müller CE, Fermentation patterns of small-bale silage and haylage produced as a feed for horses. Grass Forage Sci. 60:109-118 (2005).

33. Kung $\mathrm{L}$ and Shaver R, Interpretation and use of silage fermentation analysis reports. Focus on Forage 3:13 1-5 (2001).

34. Zucali M, Bava L, Tamburini A, Brasca M, Vanoni L and Sandrucci A, Effects of season, milking routine and cow cleanliness on bacterial and somatic cell counts of bulk tank milk. J Dairy Res 78:436-441 (2011).

35. Klijn N, Nieuwenhof FFJ, Hoolwerf JD, van der Waals CB and Weerkamp AH, Identification of Clostridium tyrobutyricum as the causative agent of late blowing in

Formatted: Font: Italic 
1

2

3

4

5

6

7

8

9

10

11

12

13

14

15

16

17

18

19

20

21

22

23

24

25

26

27

28

29

30

31

32

33

34

35

36

37

38

39

40

41

42

43

44

45

46

47

48

49

50

51

52

53

54

55

56

57

58

59

60

cheese by species-specific PCR amplification. Appl Environ Microbiol 61:29192924 (1995).

36. Rossi F and Dellaglio F, Quality of silages from Italian farms as attested by number and identity of microbial indicators. J Appl Microbiol 103:1707-1715 (2007). 
Table 1. Chemical composition, nutritive and anaerobic bacterial spore count of forages (Least square means values)

\begin{tabular}{|c|c|c|c|c|c|c|c|c|c|c|c|}
\hline & $\mathrm{n}$ & $\begin{array}{c}\mathrm{DM} \\
\mathrm{g} \mathrm{kg}^{-1}\end{array}$ & $\begin{array}{c}\text { Ash } \\
\mathrm{g} \mathrm{kg}^{-1} \mathrm{DM}\end{array}$ & $\begin{array}{c}\mathrm{EE} \\
\mathrm{g} \mathrm{kg}^{-1} \mathrm{DM}\end{array}$ & $\begin{array}{c}\mathrm{CP} \\
\mathrm{g} \mathrm{kg}^{-1} \mathrm{DM}\end{array}$ & $\begin{array}{c}\text { NDF } \\
\mathrm{g} \mathrm{kg}^{-1} \mathrm{DM}\end{array}$ & $\begin{array}{c}\mathrm{ADF} \\
\mathrm{g} \mathrm{kg}^{-1} \mathrm{DM}\end{array}$ & $\begin{array}{c}\mathrm{ADL} \\
\mathrm{g} \mathrm{kg}^{-1} \mathrm{DM}\end{array}$ & $\begin{array}{c}\text { ASFB } \\
\log _{10} \mathrm{MPN} \\
\mathrm{g}^{-1}\end{array}$ & $\begin{array}{c}\mathrm{NE}_{1} 3 \mathrm{x} \\
\mathrm{MJ} \mathrm{kg}^{-1} \\
\mathrm{DM}\end{array}$ & $\begin{array}{l}\text { NDFD } \\
\mathrm{g} \mathrm{kg}^{-1}\end{array}$ \\
\hline \multicolumn{12}{|l|}{ Alfalfa } \\
\hline silage & 6 & $564 \mathrm{~b}$ & $97.3 b$ & $19.5 \mathrm{bc}$ & $184 a$ & 456 & $397 b$ & $99.7 b$ & 3.00 & $4.88 \mathrm{a}$ & $383 b$ \\
\hline hay & 3 & $924 a$ & $70.3 c$ & $13.1 \mathrm{~cd}$ & $138 b$ & 559 & $498 \mathrm{a}$ & $129 \mathrm{a}$ & 2.30 & $3.63 b$ & $281 \mathrm{c}$ \\
\hline \multicolumn{12}{|l|}{ Grass } \\
\hline silage & 2 & $394 \mathrm{c}$ & $133 a$ & $24.0 \mathrm{ab}$ & $90.0 \mathrm{~cd}$ & 471 & $360 \mathrm{~b}$ & $56.5 \mathrm{~d}$ & 3.46 & $4.75 \mathrm{a}$ & $466 a b$ \\
\hline hay & 18 & $916 a$ & $76.2 \mathrm{c}$ & $15.6 \mathrm{~cd}$ & $89.7 \mathrm{~d}$ & 557 & $360 \mathrm{~b}$ & $57.6 \mathrm{~d}$ & 2.59 & $4.90 \mathrm{a}$ & $488 \mathrm{ab}$ \\
\hline \multicolumn{12}{|l|}{ Italian ryegrass } \\
\hline silage & 6 & $412 \mathrm{c}$ & $105 b$ & $30.2 \mathrm{a}$ & $113 b c$ & 577 & $365 b$ & $73.8 \mathrm{~cd}$ & 3.28 & $4.95 \mathrm{a}$ & $578 \mathrm{a}$ \\
\hline hay & 2 & $927 \mathrm{a}$ & $67.3 \mathrm{c}$ & $11.6 \mathrm{~d}$ & $82.9 d$ & 554 & $396 b$ & $86.9 \mathrm{bc}$ & 2.81 & $4.25 \mathrm{ab}$ & $391 b$ \\
\hline $\mathrm{SE}^{\mathrm{e}}$ & & 47.3 & 9.60 & 3.40 & 15.7 & 36.1 & 34.8 & 12.8 & 0.66 & 0.39 & 47.9 \\
\hline $\mathrm{P}^{\mathrm{f}}$ forage species & & 0.08 & 0.01 & 0.16 & $<0.001$ & 0.100 & 0.004 & $<0.001$ & 0.65 & 0.15 & $<0.001$ \\
\hline P type of conservation & & $<0.001$ & $<0.001$ & $<0.001$ & 0.05 & 0.007 & 0.04 & 0.07 & 0.09 & 0.02 & 0.007 \\
\hline P forage* conservation & & 0.10 & 0.13 & 0.04 & 0.13 & 0.10 & 0.14 & 0.34 & 0.91 & 0.06 & 0.02 \\
\hline
\end{tabular}

DM, dry matter; EE, ether extract; CP, crude protein; NDF, neutral detergent fiber; ADF, acid detergent fiber; ADL, acid detergent lignin; ASFB, anaerobic spore forming bacteria; $\mathrm{NE}_{1} 3 \mathrm{x}$, net energy of lactation computed three times at maintenance; NDFD, rumen neutral detergent fiber digestibility with an incubation time of 48 hours.

${ }^{a, b, c, d}$ Least square means within column with different superscript correspond to significant difference for $\mathrm{P}<0.05$

${ }^{\mathrm{e}} \mathrm{SE}$ : standard error

${ }^{\text {f}} \mathrm{P}:$ probability 
Table 2. Farm distribution and anaerobic spore forming bacteria count in bulk tank milk $\left(\log _{10}\right.$ MPN $\mathrm{L}^{-1}$ ) considering silage quality

\begin{tabular}{|c|c|c|c|}
\hline & \multirow[b]{2}{*}{ No. farms } & \multicolumn{2}{|c|}{$\begin{array}{c}\text { Anaerobic spore forming } \\
\text { bacteria count }\left(\log _{10} \mathrm{MPN}^{\mathrm{a}} \mathrm{L}^{-1}\right. \\
\text { milk) }\end{array}$} \\
\hline & & Mean & $\mathrm{SD}^{\mathrm{b}}$ \\
\hline \multicolumn{4}{|l|}{ Farms size } \\
\hline lactating cows $<100$ & 12 & 2.78 & 0.60 \\
\hline lactating cows $>100$ & 11 & 2.72 & 0.45 \\
\hline \multicolumn{4}{|l|}{ Grass and alfalfa silage } \\
\hline NO & 11 & 2.78 & 0.37 \\
\hline YES & 12 & 2.73 & 0.65 \\
\hline \multicolumn{4}{|l|}{ Corn silage quality } \\
\hline $\mathrm{pH}<3.8$ & 4 & 3.02 & 0.36 \\
\hline $\mathrm{pH}>3.8$ & 19 & 2.70 & 0.54 \\
\hline lactic acid $<50 \mathrm{~g} \mathrm{~kg}^{-1} \mathrm{DM}^{\mathrm{c}}$ & 10 & 2.88 & 0.31 \\
\hline lactic acid $>50 \mathrm{~g} \mathrm{~kg}^{-1} \mathrm{DM}$ & 13 & 2.65 & 0.64 \\
\hline acetic acid $<20 \mathrm{~g} \mathrm{~kg}^{-1} \mathrm{DM}$ & 12 & 2.85 & 0.38 \\
\hline acetic acid $>20 \mathrm{~g} \mathrm{~kg}^{-1} \mathrm{DM}$ & 11 & 2.65 & 0.66 \\
\hline propionic acid $<1.5 \mathrm{~g} \mathrm{~kg}^{-1} \mathrm{DM}$ & 13 & 2.60 & 0.52 \\
\hline propionic acid $>1.5 \mathrm{~g} \mathrm{~kg}^{-1} \mathrm{DM}$ & 10 & 2.96 & 0.48 \\
\hline N_NH 3 corn silage $<10 \%$ total $\mathrm{N}$ & 10 & 2.78 & 0.40 \\
\hline $\mathrm{N} \_\mathrm{NH}_{3}$ corn silage $>10 \%$ total $\mathrm{N}$ & 13 & 2.73 & 0.62 \\
\hline \multicolumn{4}{|l|}{$T M R^{\bar{d}}$ spore count } \\
\hline $\log _{10} \mathrm{MPN} \mathrm{g}^{-1}<4.7$ & 10 & 2.61 & 0.57 \\
\hline $\log _{10} \mathrm{MPN} \mathrm{g}^{-1}>4.7$ & 13 & 2.86 & 0.48 \\
\hline \multicolumn{4}{|l|}{ Corn silage spore count } \\
\hline $\log _{10} \mathrm{MPN} \mathrm{g}^{-1}<2.3$ & 10 & 2.49 & 0.53 \\
\hline $\log _{10} \mathrm{MPN} \mathrm{g}^{-1}>2.3$ & 11 & 3.00 & 0.40 \\
\hline
\end{tabular}

${ }^{\mathrm{a}} \mathrm{MPN}$ : Most probable number

${ }^{\mathrm{b}} \mathrm{SD}$ : standard deviation

${ }^{\mathrm{c}}$ DM: dry matter

d TMR: total mixed ration 
Table 3. Farm distribution and anaerobic spore forming bacteria count in bulk tank milk $\left(\log _{10}\right.$ MPN $\mathrm{L}^{-1}$ ) considering management practices

\begin{tabular}{|c|c|c|c|}
\hline & \multicolumn{3}{|c|}{$\begin{array}{l}\text { Anaerobic spore forming } \\
\text { bacteria count } \\
\log _{10} \mathrm{MPN}^{\mathrm{a}} \mathrm{L}^{-1} \mathrm{milk}\end{array}$} \\
\hline & No. farms & Mean & $\mathrm{SD}^{\mathrm{b}}$ \\
\hline \multicolumn{4}{|l|}{ Udder hygiene } \\
\hline dirty udder $<40 \%{ }^{\mathrm{c}}$ & 13 & 2.58 & 0.49 \\
\hline dirty udder $>40 \%$ & 10 & 2.98 & 0.51 \\
\hline \multicolumn{4}{|l|}{ Milking routine } \\
\hline use of gloves: NO & 12 & 2.81 & 0.51 \\
\hline use of gloves: YES & 11 & 2.7 & 0.56 \\
\hline \multicolumn{4}{|l|}{ Dry udder clean } \\
\hline $\mathrm{NO}$ & 7 & 2.73 & 0.36 \\
\hline YES & 16 & 2.76 & 0.6 \\
\hline \multicolumn{4}{|l|}{ Forestripping } \\
\hline NO & 9 & 2.92 & 0.51 \\
\hline YES & 14 & 2.65 & 0.53 \\
\hline \multicolumn{4}{|l|}{ Predipping } \\
\hline NO & 14 & 2.79 & 0.49 \\
\hline YES & 9 & 2.69 & 0.6 \\
\hline \multicolumn{4}{|l|}{ Postdipping } \\
\hline $\mathrm{NO}$ & 8 & 2.76 & 0.58 \\
\hline YES & 15 & 2.75 & 0.52 \\
\hline \multicolumn{4}{|c|}{ Milking routine: no. operations } \\
\hline 0 & 1 & 2.69 & . \\
\hline 1 & 6 & 2.81 & 0.67 \\
\hline 2 & 2 & 2.78 & 0.37 \\
\hline 3 & 3 & 3 & 0.44 \\
\hline 4 & 9 & 2.74 & 0.31 \\
\hline 5 & 2 & 2.27 & 1.36 \\
\hline
\end{tabular}

${ }^{a} \mathrm{MPN}$ : most probable number

${ }^{\mathrm{b}} \mathrm{SD}$ : standard deviation

${ }^{\mathrm{c}}$ Dirty udder: \% of udder with hygiene score 3 and 4 
1

2

Table 4. Frequency of different Clostridium species detected in forage, TMR and milk samples.

\begin{tabular}{lccccc}
\hline & & Cl. beijerinckii & Cl. butyricum & Cl. sporogenes & Cl. tyrobutyricum \\
\hline Corn silage & $\mathrm{n}$ & yes & yes & yes & yes \\
Grass hay & 21 & 5 & 5 & 2 & 14 \\
Grass silage & 18 & 4 & 5 & 6 & 14 \\
Alfalfa hay & 2 & - & - & 1 & 2 \\
Alfalfa silage & 3 & - & - & 1 & 1 \\
Italian ryegrass hay & 6 & 2 & 1 & 1 & 4 \\
Italian ryegrass silage & 2 & - & - & 1 & 1 \\
TMR & 6 & - & - & 1 & 3 \\
Milk & 23 & 10 & 7 & 1 & 19 \\
\hline
\end{tabular}


Table 5. Characteristics of the farms classified on the basis of HIGH or LOW milk anaerobic spore forming bacteria (Least square means)

\begin{tabular}{|c|c|c|c|c|}
\hline & HIGH & LOW & $\mathrm{SE}^{\mathrm{a}}$ & $\mathrm{P}^{\mathrm{b}}$ \\
\hline Farms, no. & 12 & 11 & & \\
\hline Farm size, no. lactating cows & 98.5 & 109 & 7.31 & 0.33 \\
\hline Total farm land, ha & 49.5 & 42.3 & 6.67 & 0.45 \\
\hline \multicolumn{5}{|l|}{ Milk production } \\
\hline Milk yield, cow day ${ }^{-1}$ & 23.3 & 28.2 & 1.25 & 0.01 \\
\hline Fat, $\mathrm{g} \mathrm{kg}^{-1}$ & 38.9 & 38.8 & 0.43 & 0.83 \\
\hline Protein, $\mathrm{g} \mathrm{kg}^{-1}$ & 35.1 & 35.0 & 0.21 & 0.75 \\
\hline Lactose, $\mathrm{g} \mathrm{kg}^{-1}$ & 50.0 & 50.1 & 0.17 & 0.48 \\
\hline Urea, $\mathrm{mg} \mathrm{dL}^{-1}$ & 20.6 & 21.6 & 1.08 & 0.50 \\
\hline Linear Score & 4.23 & 4.31 & 0.12 & 0.63 \\
\hline \multicolumn{5}{|l|}{ TMR composition } \\
\hline Forage, $\mathrm{g} \mathrm{kg}^{-1} \mathrm{DMI}^{\mathrm{c}}$ & 565 & 554 & 16.0 & 0.64 \\
\hline Grass silage, $\mathrm{g} \mathrm{kg}^{-1} \mathrm{DMI}$ & 59.6 & 51.5 & 21.4 & 0.79 \\
\hline Corn silage, $\mathrm{g} \mathrm{kg}^{-1} \mathrm{DMI}$ & 362 & 364 & 11.2 & 0.88 \\
\hline \multicolumn{5}{|l|}{ Forages spore contamination } \\
\hline Corn silage, $\log _{10} \mathrm{MPN}^{\mathrm{d}} \mathrm{g}^{-1}$ & 2.47 & 1.90 & 0.21 & 0.07 \\
\hline Grass, $\log _{10}$ MPN g ${ }^{-1}$ & 2.71 & 2.11 & 0.36 & 0.22 \\
\hline TMR, $\log _{10}$ MPN g g & 4.78 & 4.51 & 0.21 & 0.39 \\
\hline \multicolumn{5}{|l|}{ Hygiene Score } \\
\hline Udder, $\% 3+4$ & 49.6 & 31.3 & 7.78 & 0.11 \\
\hline Legs, $\% 3+4$ & 70.0 & 49.1 & 8.84 & 0.11 \\
\hline Flanks, $\% 3+4$ & 55.5 & 36.6 & 8.33 & 0.12 \\
\hline Milking routine, no. operations & 3.00 & 2.63 & 0.50 & 0.61 \\
\hline \multicolumn{5}{|l|}{ Milk bacterial counts } \\
\hline Spore count, $\log _{10} \mathrm{MPN} \mathrm{L}^{-1}$ & 3.14 & 2.33 & 0.11 & 0.00 \\
\hline $\mathrm{SPC}^{\mathrm{e}}, \log _{10} \mathrm{CFU}^{\mathrm{f}} \mathrm{mL}^{-1}$ & 4.21 & 4.09 & 0.27 & 0.75 \\
\hline Coliform, $\log _{10} \mathrm{CFU} \mathrm{mL} \mathrm{mL}^{-1}$ & 1.76 & 2.54 & 0.29 & 0.07 \\
\hline Lactic acid bacteria, $\log _{10} \mathrm{CFU} \mathrm{mL} \mathrm{m}^{-1}$ & 3.83 & 3.77 & 0.14 & 0.74 \\
\hline Propionibacteria, $\log _{10} \mathrm{CFU} \mathrm{mL} \mathrm{m}^{-1}$ & 1.85 & 2.16 & 0.23 & 0.36 \\
\hline
\end{tabular}

${ }^{a}$ SE: standard error

${ }^{\mathrm{b}} \mathrm{P}$ : probability

${ }^{c}$ DMI: dry matter intake

${ }^{\mathrm{d}}$ MPN: most probable number 


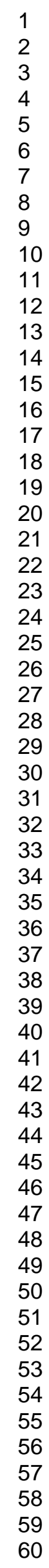

eSPC: standard plate count

${ }^{\mathrm{f}} \mathrm{CFU}$ : colony forming unit 
Figure 1. Multiple corrispondence analysis of risk factors for spore contamination in milk of 23 farms 
Figure 2. X-Ray analysis of cheese wheels produced WITH and WITHOUT the addition of lysozyme from HIGH and LOW milk group

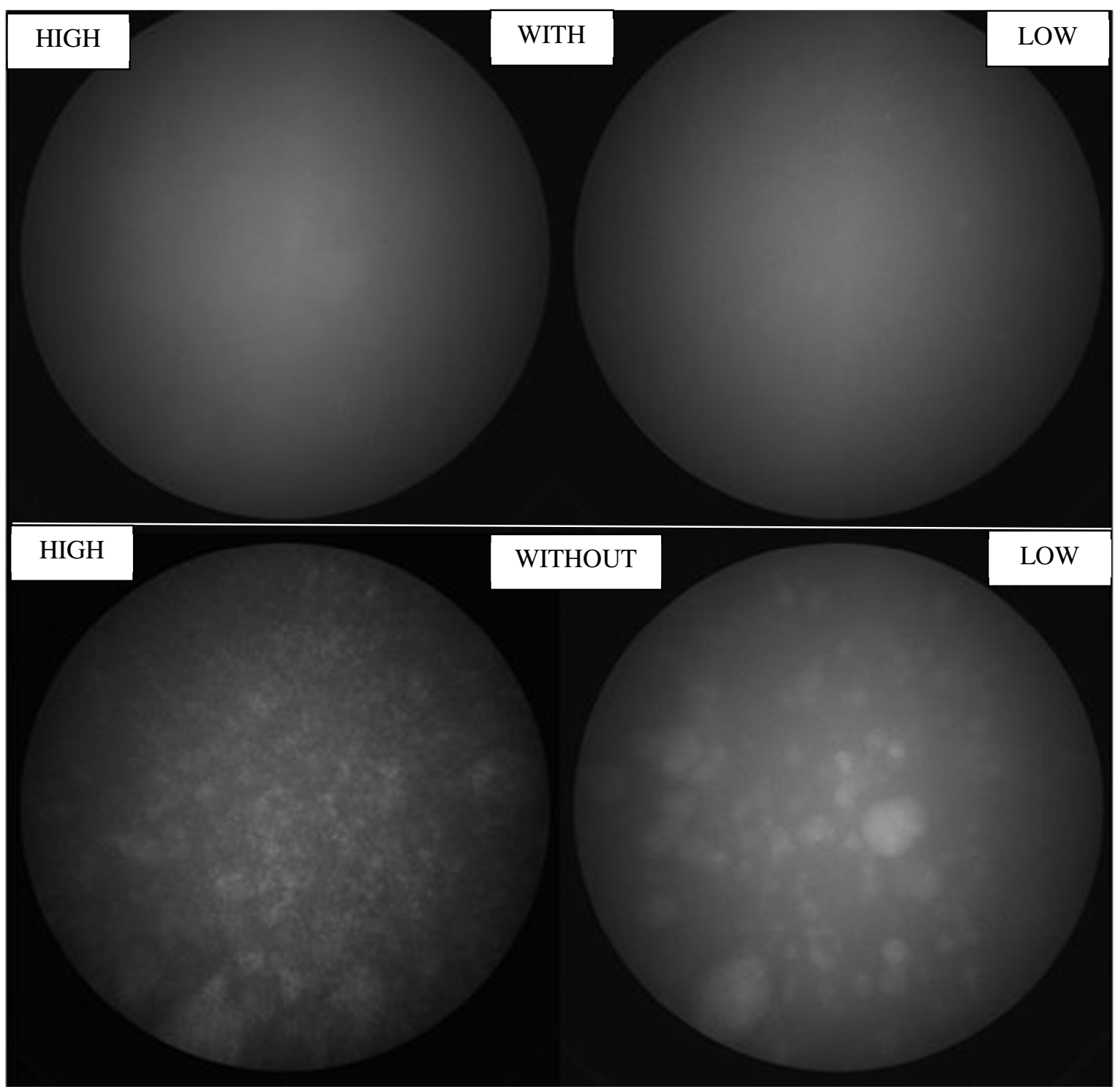

